\title{
Health economics, equity, and efficiency: are we almost there?
}

This article was published in the following Dove Press journal:

ClinicoEconomics and Outcomes Research

12 February 2015

Number of times this article has been viewed

\author{
Marcos Bosi Ferraz ${ }^{1,2}$ \\ 'Department of Medicine, Escola \\ Paulista de Medicina, Federal \\ University of São Paulo, São Paulo, \\ Brazil; ${ }^{2}$ São Paulo Center for Health \\ Economics (GRIDES), Escola Paulista \\ de Medicina, Federal University of São \\ Paulo, São Paulo, Brazil
}

\begin{abstract}
Health care is a highly complex, dynamic, and creative sector of the economy. While health economics has to continue its efforts to improve its methods and tools to better inform decisions, the application needs to be aligned with the insights and models of other social sciences disciplines. Decisions may be guided by four concept models based on ethical and distributive justice: libertarian, communitarian, egalitarian, and utilitarian. The societal agreement on one model or a defined mix of models is critical to avoid inequity and unfair decisions in a public and/or private insurance-based health care system. The excess use of methods and tools without fully defining the basic goals and philosophical principles of the health care system and without evaluating the fitness of these measures to reaching these goals may not contribute to an efficient improvement of population health.
\end{abstract}

Keywords: health care, health care system, population health

\section{Commentary}

Health care is a highly complex, dynamic, and creative sector of the economy. It "sells" hope, beyond health, in an environment of different parties, interests, and incentives. It deals with uncertainties and preferences in a context of asymmetry of knowledge, information, and power to make decisions (Ferraz, unpublished data, 2015). ${ }^{1}$ Due to its model structure (insurance), complexity, and the evolving nature of science and human expectations, health care should be planned for the long term and be based on solid ethical and distributive justice principles.

The model currently in place in most countries (public, private, or mixed health care system) is based on sharing the financial risk through an insurance system. The high degree of innovation in the sector in an environment of limited resources creates the need for timely and continuing appraisal of evidence and for understanding and integrating individual and societal sets of values and preferences when making choices.

Many health economic tools and methods have been developed and used to inform decisions. Sometimes we are somewhat distracted by the passion with some sophisticated methods and forget that the real world health care system problems and choices are much simpler (although tougher) than we expect. We are definitely not doing all we can in terms of improving population quality and quantity of life and, unfortunately, we are far from overcoming the challenge of optimizing allocative efficiency. In some specific cases, we may have improved technical and productive efficiency; however, as Peter Drucker well describes, "There is nothing quite so useless, as doing with great efficiency, something that should not be done at all".
Correspondence: Marcos Bosi Ferraz São Paulo Center for Health Economics (GRIDES), Escola Paulista de Medicina, Federal University of São Paulo, Rua Botucatu 740, 3rd floor, São Paulo, 04023-062, Brazil Email marcos.ferraz@cpes.org.br 
While health economics has to continue its efforts to improve its methods and tools to better inform decisions, the application needs to be aligned with the insights and models of other social sciences disciplines. To improve health care in our society, we will have to consider implications beyond health care.

Recently, the label "value-based decision making" has become popular to characterize what in our belief should justify our choices. However, at least two basic (but often ignored) aspects of a health care system need to be defined: 1) the economic framework in which it operates and 2) the underlying priority setting models based on ethical agreements and distributive justice.

It is important to note that health care systems built on a societal insurance model should prioritize need (demand) and not supply of products and services. Systems based on

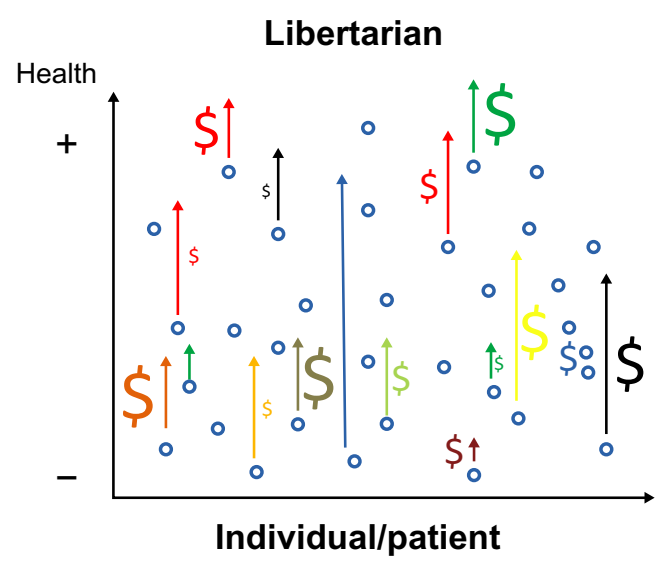

Individuals are responsible for their own health and health care. Everybody pays (directly or indirectly through insurance) for all care depending on the individually perceived need. Nobody has to take responsibility for the care of others. The economically disfavored ones depend on the philanthropy or charity for access to healthcare

\section{Communitarian}

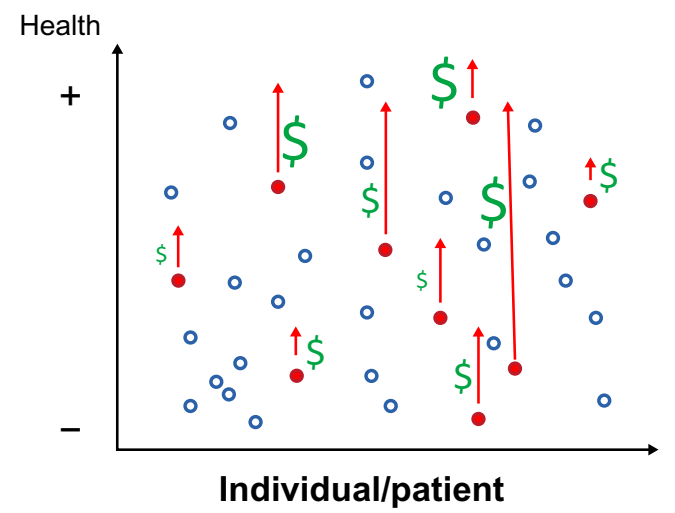

Society defines the health and health care need within the framework of societal values and preferences. Health care is not based on individual need, desire, or wants. Priority may be given to health care services for people who could not function normally as members of society. Red dots and arrows indicate priority interventions

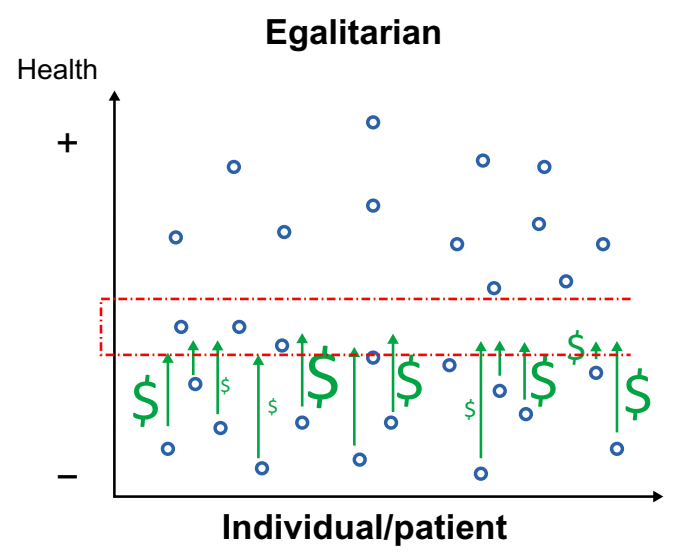

All individuals tend to be as similar as possible regarding their health or health status. It is not the individually experienced health care need that is important, but an objectively defined health care need across all diseases and disease states. The incidence or prevalence of a disease has no impact on the decision

\section{Uitlitarian}

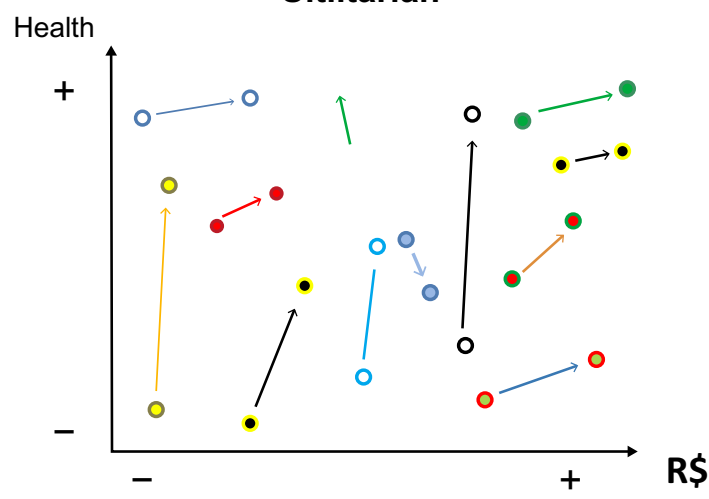

The major goals is to promote the maximum increase of population health (output), at the lowest possible consumption of resources or cost (input). High-cost interventions with low effectiveness are not prioritized. Solid lines indicate good value for money. Dotted lines do not indicate good value for money.

Figure I The graphic representation of libertarian, communitarian, egalitarian, and utilitarian models in health care. Note: Monetary (\$) amounts and different colors mean different monetary values and different payers, respectively. 
supply are much more prone to be influenced by specific interests over and above societal interests, and they usually favor abuse and waste and, consequently, increase health care inflation and disparities. Supply induces demand, which frequently may not be driven by need. ${ }^{3-5}$

Hope-driven systems, aligned with supply-driven systems, encourage premature introduction of new technologies that are not fully critically evaluated. We should aim toward systems anchored in priority setting agreements with a high preference for scientific evidence and fulfillment of health care needs, in short, value-driven systems. Concurrently, scientific progress and innovation should not be inhibited, but its uptake should be driven by market needs and be aligned to the economic perspectives. Where restrictions or barriers to the development of innovative technologies for priority areas become necessary, appropriate compensation should stimulate ongoing innovation.

In a value-driven system, decisions should be guided by transparent criteria and definitions, without prejudice for winners and losers. Faced with difficult decisions in health care, arguments of groups with particular interests based on religious, philosophical, moral, individual, or political beliefs - often win over scientific evidence or societal priority setting conventions, and any decision has the potential to be dramatically questioned by individuals and interest groups despite any strong health economics evidence.

Decisions may be guided by four concept models based on ethical and distributive justice (Figure 1): libertarian, communitarian, egalitarian, and utilitarian. ${ }^{6-10}$ Societal agreement on one model or a defined mix of models is critical to avoid inequity and unfair decisions in an insurance-based health care system.

Health care systems in many developing countries, such as Brazil, currently face major challenges: how to meet the demand for 21st century standards of health care and technology with funds that remain lower than what developed nations invested 30 years ago. ${ }^{11,12}$ Currently, Brazil invests only US $\$ 1,043$ per capita annually on health, which equals only $31 \%$ of the Organisation for Economic Co-operation and Development (OECD) average. ${ }^{13}$ Moving from a supplybased to a demand-based system and anchoring the prioritization process in a model that respects the ethical principles and favors distributive justice in health care will be essential. Right now, it is possible to identify different Brazilian health care policies that follow one of all four concept models, and we are still far from achieving any desired equity and efficiency in health care.
In conclusion, health economics should not be used as "l'art pour l'art". The excess use of methods and tools without fully defining the basic goals and philosophical principles of the health care system and without evaluating the fitness of these measures to reaching these goals may not contribute to an efficient improvement of population health.

According to Frederic Bastiat, a French political economist, an act gives birth not only to an effect, but to a series of effects. The first effect is immediate. Others may unfold in succession and often are not seen. He also defined the difference between a good and a bad economist - the one takes account of the visible effect; the other accounts for the visible effects and the ones to be foreseen. The bad economist pursues a small present good, which may be followed by a great evil to come, while the true economist pursues a great good to come, at the risk of a small present evil. ${ }^{14}$

Jorge Mautner, a Brazilian composer and singer stated in a song that "Liberty is beautiful, but it is not infinite. I do want you to believe, liberty is the consciousness of the limit!"15

To enhance the chance of achieving an equitable and efficient health care system, we have to acknowledge: 1) the need to discuss the economic model of health care systems with all ethical and distributive justice consequences; 2) the need to pursue a great good to come, at the risk of a small present evil; and 3) society has to be conscious that liberty is beautiful, but has a limit!

\section{Disclosure}

The author reports no conflicts of interest in this work.

\section{References}

1. Ferraz MB. Dilemas e Escolhas do Sistema de Saúde. São Paulo, Brazil: Medbook Editora Científica Ltda; 2008.

2. Peter Drucker Quotes [webpage on the Internet]. Available from: http:// refspace.com/quotes/Peter_Drucker/Q7405. Accessed July 11, 2014.

3. Richardson JR, Peacock SJ. Supplier-induced demand: reconsidering the theories and new Australian evidence. Appl Health Econ Health Policy. 2006;5(2):87-98.

4. Smith R. Why medicine is overweight. Don't forget inconvenient truth of supplier induced demand. BMJ. 2010;340:c3334.

5. Van Dijk CE, van der Berg B, Verheij RA, Spreeuwenberg P, Groenewegen PP, de Bakker DH. Moral hazard and supplier-induced demand: empirical evidence in general practice. Health Econ. 2013;22(3): 340-352.

6. Leget C, Hoedemaekers R. Teaching medical students about fair distribution of healthcare resources. J Med Ethics. 2007;33(12):737-741

7. Hoedemaekers R, Dekkers W. Justice and solidarity in priority setting in health care. Health Care Anal. 2003;11(4):325-343.

8. Beauchamp TL, Childress JF. Chapter 6. In: Principles of Biomedical Ethics. $5^{\text {th }}$ edition. Oxford, UK: Oxford University Press; 2001: 225-239.

9. Flood CM. International Health Care Reform: A Legal, Economic, and Political Analysis. London, UK: Routledge; 2000.

10. Scheunemann LP, White DB. The ethics and reality of rationing in medicine. Chest. 2011;140(6):1625-1632. 
11. Ferraz MB. Reconciling 21st century temptations with 20th century resources and problems. BMJ. 2006;332(7545):861.

12. Paim J, Travassos C, Almeida C, Bahia L, Macinko J. The Brazilian health system: history, advances, and challenges. Lancet. 2011; 377(9779):1778-1797.

13. OCDE Health Data. Briefing Note. How Does Brazil Compare with OCDE Countries. Available from: http://www.ocde.org/eis/healthsystems/briefing-note-BRAZIL-2013.pdf. Accessed August 11, 2014.
14. Bastiat F. What is Seen and What is not Seen. Available from: http://www. econlib.org/library/Bastiat/basEss1.html. Accessed July 11, 2014.

15. Mautner J. A consciência do limite. Available from: http://www. panfletosdanovaera.com.br/detalhe/3789. Accessed July 11, 2014.

\section{Publish your work in this journal}

ClinicoEconomics \& Outcomes Research is an international, peerreviewed open-access journal focusing on Health Technology Assessment, Pharmacoeconomics and Outcomes Research in the areas of diagnosis, medical devices, and clinical, surgical and pharmacological intervention. The economic impact of health policy and health systems organization also constitute important areas of coverage. The manuscript management system is completely online and includes a very quick and fair peer-review system, which is all easy to use. Visit http://www.dovepress.com/testimonials.php to read real quotes from published authors.

Submit your manuscript here: http://www.dovepress.com/clinicoeconomics-and-outcomes-research-journal 